University of Nebraska - Lincoln

DigitalCommons@University of Nebraska - Lincoln

Agronomy \& Horticulture -- Faculty Publications

Agronomy and Horticulture Department

2011

\title{
Biological Suppression of Velvetleaf (Abutilon theophrasti) in an Eastern Nebraska Soil
}

Jane Okalebo

University of Nebraska-Lincoln

Gary Y. Yuen

University of Nebraska-Lincoln, gyuen1@unl.edu

Rhae A. Drijber

University of Nebraska-Lincoln, rdrijber1@unl.edu

Erin E. Blankenship

University of Nebraska-Lincoln, erin.blankenship@unl.edu

Cafer Eken

Ardahan University

See next page for additional authors

Follow this and additional works at: https://digitalcommons.unl.edu/agronomyfacpub

Part of the Plant Sciences Commons

Okalebo, Jane; Yuen, Gary Y.; Drijber, Rhae A.; Blankenship, Erin E.; Eken, Cafer; and Lindquist, John L., "Biological Suppression of Velvetleaf (Abutilon theophrasti) in an Eastern Nebraska Soil" (2011). Agronomy \& Horticulture -- Faculty Publications. 613.

https://digitalcommons.unl.edu/agronomyfacpub/613

This Article is brought to you for free and open access by the Agronomy and Horticulture Department at DigitalCommons@University of Nebraska - Lincoln. It has been accepted for inclusion in Agronomy \& Horticulture -Faculty Publications by an authorized administrator of DigitalCommons@University of Nebraska - Lincoln. 


\section{Authors}

Jane Okalebo, Gary Y. Yuen, Rhae A. Drijber, Erin E. Blankenship, Cafer Eken, and John L. Lindquist 


\section{AddingValue to Graduate Education: The Comprehensive Examination}

Virtually all graduate study requirements for M.S. or Ph.D. degrees include a written comprehensive and an oral exam, the latter most often a presentation of thesis or dissertation results. The written exam takes many forms, but the goals are to test the candidate for technical competence and affirm that the prior program course work has been effective in bringing the candidate to an acceptable level of understanding of the discipline in which she or he has 
been immersed. Although long accepted as a useful hurdle on the path to a degree, for some exceptional students who have already demonstrated competence in multiple ways, especially at the Ph.D. level, this has become an unnecessary chore for both students and supervisory committee members. All would rather devote quality time to something valuable for the student, rather than just busy work to re-validate what everyone already knows about the candidate. We have tested a new method of examination in a few situations, one that is focused on the student's ability to explain science to a lay audience.

Learning objectives are to 1) encourage the student to reflect on the broad importance of the courses and research project and how this can impact society, and 2) practice writing for a general audience about the topics of courses or research. With current skepticism about science and our research in many quarters, it is increasingly important to find effective ways to communicate with the public.

Methods include the framing of comprehensive exam questions that lend themselves to interpretation, clear articulation, and application to society's perceived challenges - quite a different challenge than writing for a journal. A recent comprehensive exam at University of Nebraska for a PhD student in practical applications of his research on use of diverse cover crop mixtures in sustainable farming systems included these five questions:

1. Select one important topic in soil microbiology relevant to organic agriculture and write an essay for a popular publication

2. What is a standard error? Explain this calculation and concept to a general audience outside of academia

3. Your research on mixtures of cover crops has potentially wide impacts on design of future farming systems; describe this practice to a general audience

4. Write an essay for the general public discussing the environmental benefits and drawbacks of agricultural intensification compared to organic agriculture

5. You have just been appointed to a farming systems and organic agriculture position at a major Land Grant University; using the advertised position description, prepare a draft of your first Hatch project

There were no further guidelines, nor time constraints put on the student to answer these questions, but rather he was urged to do as well as possible with the idea of submitting one or more of them for publication in a general interest journal in agriculture, natural sciences, or related area.

Observed impacts of this type of comprehensive exam were both immediate and striking. The student said up front in a meeting with the committee that this assignment "raised the stakes" of the exercise, since he understood that some of the results would actually be published, and not just languish in the file of his supervisory committee. It was also said to be a new way of looking at science, and a challenge to write in a way and with language that was comprehensible to a lay audience. In fact, by the time of the oral exam over the questions, one had already been submitted and accepted for publication in PrairieFire Newspaper, a publication from Lincoln, Nebraska that circulates across the Great Plains (Wortman and Francis, 2011)..

Another $\mathrm{PhD}$ student in Agricultural Leadership, Education and Communications was afforded the same opportunity as an alternative to the traditional comprehensive examination. She had two articles accepted and published in this same regional publication, in the June and July 2011 issues (Quinn and Francis, 2011a, 2011b). These follow on a theme of two previous student articles in PrairieFire, one last August on the history of organic certification, and one early this year on the importance of introducing local and organic foods into schools.

Supervisory committee members for these students were equally pleased with the results. Since they already had the grad students in class and knew their technical capabilities, it was good to present a new type of challenge rather than revisit topics where the candidate's legitimacy had already been established. We do recognize that this approach is not necessarily for all students, and that the comprehensive written exam is an important way to assess technical knowledge. But for some students we feel that this is an innovative approach to broadening the capacities of a young professional to reach the general public.

\section{References}

Quinn, C., and C. Francis. 2011a. Agricultural ethics and USDA organic standards. Prairie Fire Newspaper 5(7):9-11.

Quinn, C., and C. Francis. 2011b. Organic philosophy impacts U.S. food system. Prairie Fire Newspaper 5(6):15-18.

Wortman, S., and C. Francis. 2011. Cover crops: increasing diversity in Nebraska crop rotations. Prairie Fire Newspaper 5(8):2, 9-11, 14.

Submitted by:

John Lindquist, Sam Wortman, and Charles Francis, University of Nebraska-Lincoln 